\title{
The Applicability of the Antitrust Laws to International Cartels Involving Foreign Governments
}

\author{
Awed by the unparalleled success of the Organization of Petroleum Ex- \\ porting Countries (OPEC), foreign governments have become increasingly \\ willing to orchestrate and participate in international cartels. ${ }^{1}$ These \\ "multiple-nation" cartels ${ }^{2}$ directly harm the United States by siphoning \\ off our country's wealth. They indirectly injure the United States (as well \\ as other nations) by creating allocative and productive inefficiencies ${ }^{3}$ and
}

1. Under a typical cartel arrangement, members seek to reduce their production in concert in order to raise prices above the long-run competitive equilibrium level. The incentive to cartelize, therefore, depends upon the monopoly profits available, which are a function of the price elasticity of demand as well as the price elasticity of supply from non-cartel producers. See Weintraub, The Example of OPEC and the Possibility of Other Producer Cartels, 24 AM. U.L. REV. 1097, 1103 (1975) (prospects for cartelization are greatest where short-run demand and supply elasticities are low). The risk that cartelization will fail detracts from this incentive because the excess capacity elicited by price-fixing activities might precipitate ruinous competition. The prevalence of international cartels, however, suggests that the incentive to cartelize remains strong in a large number of world markets. See ORGANIZATION FOR ECONOMIC CO-OPERATION AND DEVELOPMENT, COMMITTEE OF EXPERTS ON RESTRICTIVE BUSINESS PRACTICES, EXPORT CARTELS (1974) (concluding that 589 export cartels-many of them involving enterprises of more than one country-were operating throughout Europe and the United States) [hereinafter cited as OECD REPORT]; Bergsten, Resource Scarcity: Cartelization and Contrived Shortages, 25 AM. U.L. REV. 1128, 1128 (1975) (predicting "plethora" of cartelization efforts in foreseeable future by nations producing basic commodities).

2. This Note only concerns "multiple-nation" cartels: international cartels that involve more than one government (as a participant or sponsor) and that seek to control the supply abroad of a particular commodity. Foreign governments become involved in these "multiple-nation" cartels in three ways. First, a central foreign government itself may directly participate as a member of the cartel. Second, an instrumentality of a foreign government may be a cartel participant. Third, and most common, a central foreign government may compel or authorize private parties to implement or organize a cartel. Government sponsorship of many of these privately operated cartels may often be solicited by the private actors involved. Governments can assist such cartels by forcing members to comply with cartel price and output guidelines, see, e.g., 1 International Uranium Cartel, 1977: Hearings Before the Subcomm. on Oversight and Investigations of the House Comm. on Interstate and Foreign Commerce, 95th Cong., 1st Sess. 226 (1977) (statement of Jerry McAfee, Chairman and Chief Executive Officer of Gulf Oil Corp.) (Canada refused to grant export licenses to uranium producers who failed to adhere to cartel's price schedules) [hereinafter cited as Uranium Cartel Hearings], and by enabling these private cartelists to qualify for antitrust immunity under the sovereign compulsion defense, see pp. 784-85; 1 Uranium Cartel Hearings, supra, at 242-43 (statement of Rep. Albert Gore, Jr.) (Gulf officials solicited Canadian government directives that would appear to compel cartel participation by their Canadian subsidiary).

3. Allocative inefficiency is attributable to the diversion of resources from the cartelized market to other markets where they are used in a less productive manner. See F. SCHERER, INDUSTRIAL MARKET STRUCTURE AND ECONOMIC PERFORMANCE 16-18 (2d ed. 1980) (graphic analysis of "deadweight welfare loss"). But see id. at 463-64 (citing empirical studies indicating that welfare loss from monopoly pricing will not be sizeable in a number of markets). The so-called "theory of second best" challenges this basic assumption that cartel pricing causes allocative inefficiency. According to this theory, where competitive conditions do not prevail in at least one market, cartelization (or monopolization) of another market does not necessarily worsen resource allocation. See F. SCHERER, supra, at 27-28. Even if cartelization does not breed allocative inefficiencies, it does encourage significant productive 
by precipitating the formation of additional cartels. ${ }^{4}$ It is therefore generally in the United States' interest to deter their formation or continued operation, or at least to negotiate favorable commodity agreements ${ }^{5}$ that entail less price or output distortion than might otherwise be expected from these cartels.

The availability of antitrust sanctions would further this anti-cartel objective. ${ }^{6}$ Under well-established United States case law, price fixing by international cartels operated solely by private parties constitutes a per se violation of the antitrust laws. ${ }^{7}$ Presumably, this per se rule (rather than the rule of reason) is equally applicable to multiple-nation cartels. ${ }^{8}$

inefficiencies. Id. at 464-68 (surveying theoretical and empirical literature suggesting that cartelists squander resources in maintaining market dominance, in resorting to socially suboptimal forms of non-price competition, and in tolerating excessive operating costs).

4. See OECD REPORT, supra note 1, at 51 (formation of national export cartels in one country prompted other countries to allow the formation of similar cartels).

5. Generally, international commodity agreements are implemented through one of the following mechanisms: a buffer stock arrangement; an export quota system; or multilateral (or bilateral) supply contracts. The buffer stock device entails the use of a central fund to purchase or sell the commodity when its price falls below or exceeds a prescribed range. Since this device does not control the production or sale of the commodity by the exporting nations, it can only be used to stabilize prices at the long-term competitive level. Under an export quota system, the parties first determine the aggregate quantity of exports necessary to achieve the desired price goals and then assign export quotas to the individual producer nations. If used as a method for constraining cartel pricing, the export quotas would have to be mandatory and would have to exceed the profit-maximizing output level the cartel would otherwise have set. Multilateral (or bilateral) contract arrangements provide insurance against dramatic price movements by establishing minimum and maximum prices at which importing members and exporting members guarantee a specified level of purchases and sales, respectively. The relative merits of each of these commodity control mechanisms are assessed in Symposium, International Commodity Agreements, 28 LAW \& CONTEMP. PROBS. 271 (1963); and in Note, International Commodity Agreements, 6 GA. J. INT'L \& COMP. L. 275 (1976).

6. Without antitrust sanctions, diplomacy cannot adequately deter cartel formation because it cannot impose penalties on governments and cooperative private companies that attempt to organize cartels, or force existing cartels to disgorge the monopoly profits reaped before a diplomatic agreement is reached. Moreover, the incentive to earn full monopoly profits encourages cartels to conceal their existence, see, e.g., 2 Uranium Cartel Hearings, supra note 2, at 2 (statement by Rep. Albert Gore, Jr.) (rigged bidding scheme enabled uranium cartel to elude detection for three years), and to protract negotiations. The resulting delay enables a cartel to recruit new members and to develop greater organizational cohesion, thereby impairing the ability of the executive to conclude an advantageous commodity agreement.

7. Price fixing by cartels has been condemned under $\S 1$ of the Sherman Anti-Trust Act, 15 U.S.C. $\S 1$ (1976), and under $\S 73$ of the Wilson Tariff Act, 15 U.S.C. $\S 8$ (1976), which proscribes the anticompetitive practices of importers. See, e.g., Fosburgh v. California \& Hawaiian Sugar Ref. Co., 291 F. 29, 31-32 (9th Cir. 1923); United States v. Watchmakers of Switz. Information Center, 1963 Trade Cas. (CCH) I 70,600, at 77,455-56 (S.D.N.Y. 1962), modified, 1965 Trade Cas. If 71,352 (S.D.N.Y. 1965). Courts have devoted little attention to $\$ 73$ of the Wilson Tariff Act, however, treating it as little more than a detailed exposition of the strictures of the Sherman Act. See W. FUGATE, FOREIGN COMMERCE AND THE ANTITRUST LAWS 393-98 (2d ed. 1973). For the sake of simplicity, therefore, this Note focuses on $\$ 1$ of the Sherman Act.

8. Though no case has yet addressed this issue, it is clear that the only distinguishing factor in multiple-nation cartel cases-foreign government complicity-fails to provide a sufficient basis for resorting to a rule of reason inquiry in lieu of the per se rule. The policy considerations implicated by this factor are given ample weight in the doctrines of sovereign immunity, act of state, sovereign compulsion, and judicial abstention. See infra pp. 778-88. True, these doctrines, unlike the rule of reason, would not permit the compromise approach of tolerating cartels that charge "reasonable" prices. But the policy reasons that convinced the Supreme Court to forbid consideration of the reason- 
While not questioning the applicability of the per se rule, several commentators, as well as the district and circuit courts in International Association of Machinists \& Aerospace Workers v. OPEC, ${ }^{9}$ have contended that foreign government cartelists or private cartelists acting at the behest of their host governments cannot and should not be subject to antitrust prosecution. In their view, foreign sovereigns and their instrumentalities should be sheltered from antitrust attack because the antitrust laws, properly construed, do not extend to foreign governments as antitrust defendants, and because the doctrines of sovereign immunity and act of state apply. ${ }^{10}$ They also maintain that the foreign compulsion defense insulates coerced private cartelists from antitrust liability. ${ }^{11}$ At the root of their doctrinal views lie two policy concerns: first, that antitrust sanctions would be unenforceable, ${ }^{12}$ and second, that adjudication would undermine executive foreign policy and risk calamitous international repercussions. ${ }^{13}$

This Note shows that these policy objections do not apply to a large number of multiple-nation cartel cases. The Note then demonstrates that under a proper reading of the applicable doctrines, antitrust jurisdiction over multiple-nation cartels can and should be exercised where the benefits of antitrust sanctions (taking into account the probability of successful enforcement) outweigh the adverse effects adjudication may have on foreign relations. Finally, the Note suggests legislation to enhance the utility

ableness of the pricing policy of domestic cartels have equal force in the context of multiple-nation cartels. See United States v. Trenton Potteries Co., 273 U.S. 392, $397-98$ (1927) (judiciary lacks capacity to engage in day-to-day supervision of domestic cartel's price levels, and objective standards for defining reasonableness do not exist).

9. See International Ass'n of Machinists \& Aerospace Workers v. OPEC, 477 F. Supp. 553, 576 (C.D. Cal. 1979), aff'd on other grounds, 649 F.2d 1354 (9th Cir. 1981), cert. denied, 102 S. Ct 1036 (1982).

10. See International Ass'n of Machinists \& Aerospace Workers v. OPEC, 477 F. Supp. 553, 576 (C.D. Cal. 1979) (dismissing suit on grounds that OPEC nations are entitled to sovereign immunity and are not "persons" sueable under antitrust laws), aff'd on other grounds, 649 F.2d 1354, 1361-62 (9th Cir. 1981) (dismissing on act of state grounds without reaching issues decided by district court), cert. denied, 102 S. Ct 1036 (1982); Interamerican Ref. Corp. v. Texaco Maracaibo, Inc., 307 F. Supp. 1291, 1298 (D. Del. 1970) (dictum) (foreign governments are not covered by antitrust laws); Joelson \& Griffen, The Legal Status of Nation-State Cartels Under United States Antitrust and Public International Law, $9 \mathrm{INT}^{9} \mathrm{~L}$ LAW. 617, $622-36$ (concluding that governmental cartels such as OPEC may be sheltered by the act of state and sovereign immunity doctrines).

11. See, e.g., United States v. Watchmakers of Switz. Information Center, 1963 Trade Cas. (CCH) If 70,600, at 77,456 (S.D.N.Y. 1962) (dictum) (no antitrust liability would have resulted if defendants' output restriction activities had been required by Swiss law), modified, 1965 Trade Cas. II 71,352 (S.D.N.Y. 1965); Baker, Antitrust Remedies Against Government-Inspired Boycotts, Shortages, and Squeezes: Wandering on the Road to Mecca, 61 CORNELL L. REV. 911, 915-27 (1976).

12. See Joelson \& Griffin, supra note 10, at 636-38; Comment, Defenses to Actions Against Foreign States Under the United States Antitrust Laws, 20 HARV. INT'L L.J. 583, 652 (1979).

13. See International Ass'n of Machinists \& Aerospace Workers v. OPEC, 649 F.2d 1354, 1361 (9th Cir. 1981) (adjudication might insult OPEC states and interfere with United States foreign policy), cert. denied, 102 S. Ct. 1036 (1982); Comment, supra note 12, at 652 (antitrust challenges to intergovernmental cartels would provoke retaliation). 
of antitrust sanctions against multiple-nation cartels.

\section{Efficacy of Antitrust Enforcement Against Multiple-Nation Gartels}

Exposing multiple-nation cartels to the antitrust laws would provide the executive with a potent foreign policy weapon. In addition to being enforceable against many of these cartels, antitrust sanctions can be effectively integrated into the executive's anti-cartel strategies despite the judiciary's ultimate control over antitrust proceedings.

\section{A. Impact of Antitrust Adjudication on Executive Foreign Policy}

The availability of antitrust sanctions would greatly bolster diplomatic efforts by the executive to inhibit intergovernmental cartelization. In view of its ability to immunize cartels from antitrust prosecution by negotiating a commodity agreement, ${ }^{14}$ the executive may use antitrust sanctions to pursue whichever anti-cartel strategy (whether outright suppression or negotiated compromise) it deems appropriate in a particular situation. If the executive opts for open competition, the risk of antitrust liability would deter the formation or continuation of the multiple-nation cartel involved. If the executive wishes to negotiate a commodity agreement, the danger of antitrust sanctions would provide an incentive for the cartel to engage in diplomatic discussions and to succumb to the executive's bargaining demands. If an antitrust suit is brought before the executive can initiate or conclude negotiations, the court could stay the proceedings pending resolution of the executive's negotiating efforts. If the executive

14. Such diplomatic agreements clearly supersede the antitrust laws if ratified through the treaty procedure, negotiated pursuant to a statute or joint resolution of Congress, or subsequently sanctioned by Congress. See McDougal \& Lans, Treaties and Congressional-Executive or Presidential Agrecments: Interchangeable Instruments of National Policy: I, 54 YALE L.J. 181 (1945). Even if the imprimatur of Congress is not forthcoming, the executive's inherent constitutional power over foreign affairs should endow its commodity agreements with the force of law, except, perhaps, those that conflict with the antitrust laws. See United States v. Curtiss-Wright Export Corp., 299 U.S. 304 (1936) (emphasizing broad scope of foreign affairs power). But see Consumers Union v. Rogers, 352 F. Supp. 1319 (D.D.C. 1973), aff'd as modified sub nom. Consumers Union v. Kissinger, 506 F.2d 136 (D.C. Cir. 1974) (dictum subsequently vacated by D.C. Circuit) (executive has no authority to exempt "voluntary" steel import quotas from antitrust laws), cert. denied, 421 U.S. 1004 (1975). In any event, the antitrust laws would not invalidate those commodity agreements negotiated by the executive because (1) the application of antitrust sanctions would not elicit a greater expansion in the cartel's output (due to enforcement problems, perhaps) or (2) the additional benefits of antitrust enforcement would be eclipsed by adverse foreign policy repercussions. If animated by the first motive, the executive commodity agreement would comport with the consumer welfare policies underlying the antitrust laws. If foreign policy concerns provided the impetus for the executive agreement, the act of state or judicial abstention doctrine would probably render the antitrust laws inapplicable to the cartel. However, the antitrust laws may condemn executive commodity agreements used to elicit additional output restrictions for the benefit of American industry. See Comment, Executive Authority and Antitrust Considerations in "Voluntary" Limits on Steel Imports, 118 U. PA. L. REV. 105 (1969) (concluding that antitrust laws were infringed by steel import restraints, which State Department negotiated at behest of United States steel corporations). 
informs the court that any effort to restrain the cartel is contrary to United States foreign policy, the court could dismiss the case under the judicial abstention doctrine. ${ }^{15}$

\section{B. Effectiveness of Monetary and Injunctive Sanctions Against Multi- ple-Nation Cartels}

The deterrence benefits of enforceable treble damage judgments are manifest, but the likelihood of successful enforcement will vary, depending largely on the ability of cartelists (both government and private) to remove their assets from the United States, the applicability of the execution immunity provisions of the Foreign Sovereign Immunities Act of 1976 (FSIA) $^{16}$ to foreign government cartelists, and the willingness of foreign courts to execute such judgments. By contrast, injunctive relief barring importation of any "price-fixed" goods can be readily enforced against private and government cartelists, though such measures may be counterproductive in certain situations.

\section{The Deterrent Impact of Enforceable Monetary Antitrust Sanctions}

Clearly, the spectre of enforceable treble damages would prompt foreign governments either to refrain from cartel price fixing or to accede to commodity agreements establishing less restrictive output levels. Similarly, the prospect of antitrust prosecution would give private companies an incentive to resist host government directives to cartelize or at least to persuade their government sponsors to reach agreement with the executive. Many of these private companies enjoy considerable political and economic influence ${ }^{17}$ in their host countries. Joint bargaining by these companies as buyers (if vertically integrated downstream) or as producers would augment their power. ${ }^{18}$ In many situations, the pressures they could bring to bear

15. See infra pp. 786-88.

16. 28 U.S.C. $\S \S 1602-1611$ (1976).

17. The power of these private actors, typically large multinational enterprises, stems from their ability to shift preduction among plants in various countries, to withdraw or discontinue investments, and to cease transfers of technology. See S. ROBOCK, K. SIMMONDS, \& J. ZWICK, INTERNATIONAL BUSINESS AND MULTINATIONAL ENTERPRISES 245-46, 255, 260 (rev. ed. 1977).

18. Such buyer or producer groups may appear to infringe the antitrust laws because joint action necessarily restrains the individual firm's freedom of action and involves an implicit or explicit threat of a group boycott, which is a per se antitrust violation under ordinary domestic circumstances, see, c.g., Klors, Inc. v. Broadway-Hale Stores, 359 U.S. 207 (1959). But the likelihood that most countervailing cartels would enhance consumer welfare provides a persuasive reason for allowing such collaboration. See Davidow, Antitrust, Foreign Policy, and International Buying Cooperation, 84 YALE L.J. 268, 278-89 (1974). Indeed, only those buyer or producer cartels that have both the incentive and the power to compel the foreign government cartelists to restrict further output will result in higher consumer price levels. See P. AREEDA \& D. TURNER, 2 ANTITRUST LAW § 411b, at 311-12 n.7 (1978) (incentive of countervailing cartels to curtail output further depends on the relative positions and elasticities of the demand and marginal cost curves). Even some of these cartels may pass antitrust 
against their host governments would have a decisive impact.

\section{Enforceability of Monetary Antitrust Judgments Against Multiple- Nation Cartel Participants}

The deterrent effect of the antitrust laws depends primarily on the extent to which treble damage judgments against cartel participants can be enforced. At first blush, the United States antitrust laws appear impotent against cartels comprised mostly of private actors or government entities that do not have valuable assets within the United States or whose United States assets are shielded against execution by the Foreign Sovereign Immunities Act. Careful analysis, however, suggests that such cartels are vulnerable to antitrust sanctions and that efforts by other cartels to acquire these "immunizing" traits by altering their membership or their United States operations will generally be impracticable.

\section{a. Enforceability of Monetary Antitrust Sanctions Against Private Cartelists}

The ability of private cartelists with no assets in the United States ${ }^{19}$ to evade antitrust sanctions is circumscribed in two ways. ${ }^{20}$ First, United

scrutiny on the theory that the monopoly profits they extract from foréign members of multiple-nation cartels more than offset the increased allocative inefficiency (in the United States) resulting from the additional restriction in output. Finally, even if anticompetitive consequences result, joint bargaining with the cartelizing governments (or their instrumentalities) may be sheltered from antitrust scrutiny under the so-called Noerr-Pennington doctrine, see UMW v. Pennington, 381 U.S. 657 (1965) (permitting competitors to lobby together for favorable, anticompetitive action from domestic government body); Eastern R.R. Presidents Conf. v. Noerr Motor Freight, Inc, 365 U.S. 127 (1961) (same). See Davidow, supra, at 281-82 (noting availability of Noerr-Pennington defense to groups that bargain with foreign government cartels). But see Occidental Petroleum Corp. v. Buttes Gas \& Oil Co., 331 F. Supp. 92 (C.D. Cal. 1971) (dictum) (Noerr-Pennington inapplicable to dealings with foreign governments), aff'd per curiam, 461 F.2d 1261 (9th Cir. 1972), cert. denied, 409 U.S. 950 (1972).

While no court has yet confronted the issue, the Justice Department has endorsed the organization of buyer groups to oppose the price initiatives of seller cartels. See Letter from Richard McLaren, Chief of the Antitrust Division, to Senator William Proxmire (March 5, 1971) (Antitrust Division indicated in non-binding pronouncement that it would not prosecute oil companies for bargaining jointly with OPEC because such buyer collaboration served to mitigate anticompetitive impact of OPEC) discussed in Borowitz, Joint Business Actions by Competitors: Are Any Permissible? 32 OHIO ST. L.J. 683, 686-87 (1971). But see Davidow, supra, at 281 (three years later Justice Department refused, due to changed circumstances, to extend favorable business clearance previously granted to oil companies).

19. Most private cartelists are likely to have significant assets in the United States. Empirical support for this assertion can be inferred from the following two facts: (1) multinationals are responsible for most exports from foreign countries, see S. ROBOCK, K. SIMMONDS, \& J. ZwICK, supra note 17 , at 23,31 ( $\$ 777$ billion of $\$ 848$ billion in 1974 exports from noncommunist countries attributable to multinationals), and (2) most multinationals are headquartered in the United States, and many of the rest have substantial assets in the United States, id. at 21 (multinationals with U.S. headquarters accounted for 48 percent of total book value of direct foreign investment in 1974).

20. Withdrawal of the alien private cartelist's assets from the United States would not defeat in personam jurisdiction under $\S 12$ of the Clayton Act, 15 U.S.C. $\S 22$ (1976), or under the long-arm statutes of most states. The remaining contacts between these cartelists and the United States-the 
States judgments against private cartel members may be recognized and executed by courts in foreign countries in which these cartelists have substantial assets, ${ }^{21}$ although the transnational enforceability of these judgments will largely depend on the existence of jurisdiction ${ }^{22}$ under the applicable law of the foreign country. ${ }^{23}$ Second, the accounts receivable arising from an alien cartelist's United States sales could also be subject to

deliberate and significant impact of their price-fixing activities on the United States economy and the substantiality of their United States sales-are still sufficient to satisfy the jurisdictional requirements of these statutes. See Outboard Marine Corp. v. Pezetel, 461 F. Supp. 384, 393-94 (1978); Hitt v. Nissan Motor Co., 399 F. Supp. 838 (S.D. Fla. 1975), vacated on other grounds sub. nom. In re Nissan Motor Corp. Antitrust Litigation, 552 F.2d 1088 (5th Cir. 1977); Pacific Tobacco Corp. v. American Tobacco Co., 338 F. Supp. 842 (D. Ore. 1972). Even if these contacts are insufficient to establish personal jurisdiction, the Justice Department could induce foreign cartelists to submit voluntarily to the court's jurisdiction by threatening to seize their "price-fixed" goods pursuant to $\S 6$ of the Sherman Act, 15 U.S.C. $\S 6$ (1976), and section 76 of the Wilson Tariff Act, 15 U.S.C. $\S 11$ (1976). See W. FUGATE, supra note 7, at 108-11 (discussing the several occasions when Justice Department used this tactic).

21. But see Protection of Trading Interests Act, 1980, ch. 11 (prohibiting enforcement by British courts of any foreign antitrust judgment that awards punitive damages or is based on antitrust law designated unenforceable by British Secretary of State); Forcign Antitrust Judgments (Restriction of Enforcement) Act, No. 13, Austl. Acts (1979) (permitting Australian Attorney General to prohibit or restrict enforcement of foreign antitrust judgments).

22. Typically, a foreign country would also condition transnational enforcement on a showing that (1) the defendant was given adequate notice and an opportunity to be heard; (2) enforcement would not be manifestly repugnant to public policy; (3) the judgment was not obtained by fraud; and (4) similar judgments rendered in the enforcing country would receive reciprocal enforcement in United States courts. See Zaphiriou, Transnational Recognition and Enforcement of Civil Judgments, 53 NOTRE DAME LAW. 734 (1978).

23. Even United States judgments against cartelists that operate outside the United States (and thus rely on independent American distributors) would withstand jurisdictional scrutiny in some countries. For example, these judgments would appear to comport with Germany's expansive jurisdictional precepts. German law embraces a concept of long-arm jurisdiction similar to the United States due process standard of minimum contacts. See U. DROBNIG, AMERICAN-GERMAN PRIVATE INTERNATTONAL LAW 350 (1972) (under German law foreign judgments have sufficient jurisdictional predicate where "there is a reasonable connection with the persons or the subject matter of the litigation"). Indeed, Germany's own antitrust statute reaches extraterritorial conduct that has anticompetitive effects within its borders. See J. RAHL, COMMON MARKET AND AMERICAN ANTITRUST 147 (1970); see also H. STEINER \& D. VAGTS, TRANSNATIONAL LEGAL PROBLEMS 753-54 (1976) (Section 32 of German Code construed to permit exercise of jurisdiction where effects of wrongful conduct occured).

French law would also appear to permit enforcement of United States judgments against nonFrench cartel participants having minimal contacts with the United States. Sce id. at 751 (Article 14 of the French Code allows assertion of jurisdiction over non-resident aliens for "obligations"-including torts, contract breaches and other legal duties-incurred in a foreign country towards French nationals). But see Convention of 27 September 1968 on Jurisdiction and Enforcement of Judgments in Civil and Commercial Matters, art. 3, in OFFICIAL JOURNAL OF THE EUROPEAN COMMUNITIES L. 299/32 (1972) (forbidding use of Article 14's exorbitant jurisdictional theory against EEC defendants). United States judgments against French cartelists, however, will not pass jurisdictional muster. See H. STEINER \& D. VAGTS, supra, at 751-52 (under Article 15 of French Code, French courts have exclusive jurisdiction over French defendants whose challenged conduct occurred in a foreign country). Moreover, the French antitrust laws may reach extraterritorial conduct having effects within the nation, suggesting that the applicability of United States antitrust laws to extraterritorial price fixing does not offend French concepts of subject matter jurisdiction. See Plaisant, Restrictive Trade Practices in France, in INTERNATIONAL LAW Ass'N REPORT OF THE FIFTY-SECOND CONFERENCE (HELINSKI) 89 (1966) (concluding that jurisdiction under French antitrust laws can be based on effects alone). 
execution because of their United States situs. ${ }^{24}$

Even if the absence of United States assets ensures execution immunity, many private cartelists now owning such assets would still lack sufficient incentive to withdraw or sell them. ${ }^{25}$ One major drawback to an asset removal strategy stems from the cartelist's probable inability to realize the full market value of its immovable United States assets. In the first place, such assets would have to be sold for immediate payment in liquid or nonUnited States assets to avoid creating an attachable debt; significant price concessions might have to be offered to offset this onerous term of sale. Second, because cartelization results in reduced output, the sales price for United States downstream operations would have to be lowered to compensate for the excess capacity that may develop in the downstream segments of the cartelized industry. Third, the risk that a court might regard the purchaser as an aider and abettor or co-conspirator in the cartel scheme would at least necessitate an additional price discount and may even scare off prospective buyers. ${ }^{26}$ Finally, the existence of depressed economic conditions at the time of sale, the costs of negotiating and implementing the transaction, and the tax liabilities attending it may all operate to reduce the net sales price.

Even if a cartel member could sell its United States assets at an adequate price, it would still incur other financial disadvantages as a result of its self-imposed exile. Such a cartelist would, for instance, no longer be able to exploit profitable investment opportunities in the United States. In divesting the American based segment of its cartelized operations, the cartel participant might sacrifice appreciable horizontal economies of multiplant operation as well as the vertical economies of integrated distribution and servicing networks. ${ }^{27}$ If the divested facilities include manufacturing plants, the cartelist may be forced to incur increased transportation costs as well as tariff and similar expenses in marketing its goods within the

24. See, e.g., Harris v. Balk, 198 U.S. 215 (1905) (debtor's domicile establishes situs of debt); United Bank Ltd. v. Cosmic Int'l, 542 F.2d 868 (2nd Cir. 1976) (debt incurred by Delaware corporation in accepting shipment of jute from Pakistani factories has United States situs).

25. The alternative tactic of transferring these assets to a wholly owned United States subsidiary would have no chance of success. See Annot., 122 A.L.R. 338, 340 (1939) (for purposes of execution, situs of parent's equity interest in domestic subsidiary is state where subsidiary is incorporated or where its principal business is conducted).

26. The purchaser's antitrust exposure may arise in two ways. First, the purchaser might be responsible for the pre-transaction liabilities of the cartel if it bought one or more of the cartelist's United States subsidiaries and if this subsidiary is deemed to have been a distinct cartel co-conspirator when owned by the cartelist. See Timken Roller Bearing Co. v. United States, 341 U.S. 593 (1951) (conspiracy among affiliated producers of roller bearings to divide world market violated antitrust laws). Second, the purchaser may be considered an aider and abettor on the ground that it knew or should have known that the transaction was designed to insulate the seller-cartelist from the enforcement of antitrust sanctions.

27. See generally F. SCHERER, supra note 3, at 90, 100-18, 413-22 (discussing vertical and horizontal economies). 
United States.

Thus, the withdrawal or sale of United States assets is a very costly and risky way to evade monetary antitrust sanctions. For many prospective cartel members, the possibility of successful use of this method of antitrust circumvention will be far outweighed by the risk that cartelization will fail.

\section{b. Enforceability of Antitrust Sanctions Against Foreign State Cartelists}

Foreign state cartel members that attempt to elude antitrust sanctions by withdrawing or selling their United States assets face the same problems that private cartelists employing that strategy confront. ${ }^{28}$ The Foreign Sovereign Immunities Act, however, may well provide a measure of protection to certain foreign state cartelists.

The FSIA accords a far greater degree of execution immunity to central foreign governments than to their instrumentalities. ${ }^{29}$ Antitrust judgments against an "agency or instrumentality of a foreign state engaged in commercial activity in the United States," United States property, "regardless of whether the property is or was used for the activity upon which the claim is based."31 As for "foreign states," the FSIA permits execution only against their United States property that "is or was used for the commercial activity upon which the claim is based ....".32

Accordingly, the efficacy of antitrust sanctions against foreign government cartelists depends to some extent on how broadly the phrase "foreign state agency or instrumentality" is interpreted. ${ }^{33}$ Liberally construed, it

28. See supra pp. 770-72. In particular, it should be noted that United States antitrust judgments against foreign state cartel participants might be enforceable in other countries in which they have assets. The transnational enforceability of such judgments largely depends on the availability of sovereign immunity from execution under the law of the enforcing country. In many countries, this defense does not immunize the commercial property of foreign states from execution. See, Paulsson, Sovereign Immunity from Execution in France, 11 INT'L LAW. 673, 679 (1977) (sovereign immunity defense under French law does not bar execution against foreign state property used for commercial purposes).

29. See also 28 U.S.C. $\S 1606$ (1976) (immunizing foreign states, but not foreign state agencies or instrumentalities, from punitive damages).

30. Id. $\S 1610$ (b). Any commercial activity with substantial United States contacts is a "commercial activity in the United States." See id. $\S 1603($ e). Foreign state instrumentalities having minimal but not substantial United States contacts would only be subject to the immunity exception of 28 U.S.C. $\S 1610(a)(2)(1976)$.

31. 28 U.S.C. $\& 1610($ b) (1976).

32. Id. $\S 1610(\mathrm{a})(2)$.

33. Section 1603 (a) of the FSIA states that a "foreign state" includes a "political subdivision of a foreign state or an agency or instrumentality of a foreign state . . . ." An "agency or instrumentality of a foreign state" includes legally distinct "organs" of a foreign state or legally separate entities in which a foreign state has a majority ownership interest. Id. $\$ 1603(b)$. Thus, the test for distinguishing between these two subsets of "foreign state" is whether the government entity in question has separate legal status. According to the legislative history of the FSIA, this includes any entity that 
would cover government entities that operate commercial enterprises on the ground that these government bodies are distinct from those parts of the foreign sovereign (or its political subdivisions) that engage primarily in political or governmental activities. The legislative history ${ }^{34}$ of the FSIA as well as the scant case law on point ${ }^{35}$ provide some support for this interpretation. Thus, despite the FSIA, foreign state cartelists may not be much more insulated from monetary sanctions than are private cartelists.

Even if effectively immunized from asset execution, foreign governments would still encounter formidable practical obstacles in attempting to execute a cartel scheme by themselves. If the foreign governments cartelized by jointly raising tax and royalty rates, they would encounter vigorous opposition from the private enterprises affected. ${ }^{36}$ Implementing cartel policy by nationalizing the private companies would also be disad-

"under the law of the foreign state where it was created, can sue or be sued in its own name, contract in its own name or hold property in its own name." See H.R. REP. No. 1487, 94th Cong., 2d Sess. 15 , reprinted in 1976 U.S. CODE CONG. \& AD. NEWS 6604, 6614. Failure to exhibit one of these traits, however, should not automatically disqualify a government cartel member from separate legal status. The legislative history does not indicate that these attributes form an exhaustive list. Id. Furthermore, the contrary view would have the anomalous result of equating many clearly distinct commercial entities in socialist or communist countries with their sovereign governments.

34. The House Report's reference to various commercial government entities as examples of foreign state agencies and instrumentalities, see H.R. REP. NO. 1487, supra note 33, at 16, 1976 U.S. CODE CONG. \& AD. NEWS at 6614 , suggests that separate legal status may be inferred from a government entity's involvement in a regular course of commercial conduct. Further, the bifurcation of the term "foreign state" into the central foreign government and its political subsidivions, on the one hand, and agencies and instrumentalities, on the other hand, implies that government entities that actually operate commercial enterprises should be subsumed under the latter category. Finally, to effectuate the principal objective of the commercial activity exception (that is, to hold foreign governments fully accountable for injuries resulting from their commercial activities), doubts as to the status of a government commercial entity should be resolved in favor of the agency or instrumentality classification.

35. See Outboard Marine Corp. v. Pezetel, 461 F. Supp. 384, 394 (D. Del. 1978) (classifying Polish government-owned exporter of golf carts as foreign state agency because of commercial nature of its activities). In Edlow Int'l Co. v. Nuklearna Elektrarna Krsko, 441 F. Supp. 827, 832 (D.D.C. 1977), the court held that the determination of whether an entity in a socialist country could qualify as a state agency or instrumentality would turn on "the degree to which . . . [it] discharges a governmental function, and the extent of state control over [its] operations." A similar approach could be used to distinguish between the sovereign state itself and its agencies and instrumentalities. Commercial government entities obviously would not meet the function test. Nor would they satisfy the control test in the absence of detailed governmental supervision over their daily affairs. $C f$. id. at 827,832 (governmental intrusion into daily management of entity necessary for foreign state agency or instrumentality status).

36. Even if the entire tax and royalty increase could be passed through, the private companies would still be adversely affected; the cost pass-through would significantly curb consumer demand, forcing these companies to operate at lower, less profitable capacity levels until the least efficient ones eventually exit the industry. In view of their formidable bargaining weapons, see supra p. 768 , these private companies may succeed in thwarting such a cartel scheme. Moreover, this type of cartel arrangement is particularly vulnerable because of the host governments' dependence on the private companies for the supply and demand data necessary to determine the profit maximizing price. The private companies could easily manipulate this data to yield an estimate significantly lower than the true optimal cartel price. 
vantageous because such forced buy-outs would divert scarce resources from other vital government programs, deter investment from foreign sources ${ }^{37}$ result in the loss of economies attributable to the integration of operations in the United States and the host country, ${ }^{38}$ and perhaps subject the government cartel to considerable monopsonistic pressure from its customers (probably including the former owners of the cartelized operations). ${ }^{39}$

\section{Injunctive Relief}

In those few situations in which private and foreign government cartelists can successfully evade the treble damage remedy, injunctive measures might thwart cartel price fixing. ${ }^{40}$ To be sure, injunctions that merely forbid price collusion may prove ineffective if the court is unable to enforce monetary contempt sanctions against the cartelists. But an injunction prohibiting the exportation of the cartelized goods to the United States ${ }^{41}$ could not be circumvented, since the court's contempt powers could be brought to bear on any entity that imported or distributed the "tainted" goods within the United States. ${ }^{42}$ Such an injunction would be particularly appropriate in industries in which the United States purchasers of the cartelized product are so numerous that formation of a countervailing buyer cartel would not be feasible. Because of the intricate policy issues raised and the extreme risks involved, however, courts should not fashion such extraordinary injunctive relief unless the executive expresses strong support, monetary sanctions appear ineffectual, and the United States ca-

37. See Vernon, Multinational Enterprise: Power Versus Sovereignty, in THE ECONOMIC AND Political CONSEQUENCES of MUlTinational ENTERPRISES: AN ANTHOLOGY 154 (R. Vernon ed. 1972).

38. See supra note 27.

39. Cf. supra note 18 (discussing countervailing power of buyer cartel). If large enough, individual customers can effectively exert monopsonistic pressures by dangling unusually big orders before individual cartel members or by threatening to boycott or to integrate vertically upstream. See F. SCHERER, supra note 3 , at 307-08.

40. See, e.g., United States v. Watchmakers of Switz. Information Center, 1963 Trade Cas. (CCH) II 70,600 (S.D.N.Y. 1962) (injunctive sanctions used successfully against Swiss watch manufacturers, who had restricted output with encouragement and approval of Swiss government), modified, 1965 Trade Cas. II 71,352 (S.D.N.Y.), discussed in J. RAHL, supra note 23, at 311-63.

41. Although no court has yet devised such an injunctive decree in a foreign cartel case, this unusual injunctive measure constitutes a valid exercise of the trial court's broad remedial powers. See Ford Motor Co. v. United States, 405 U.S. 562, 573 (1972) (acknowledging trial court's "large discretion" in framing antitrust decree). An importation ban would serve the two major principles of antitrust relief: to "make the remedy as effective as possible," United States v. National Lead Co., 332 U.S. 319, 334 (1947), and to deprive defendants of the fruits of their antitrust violations, see United States v. United Shoe Mach. Corp., 391 U.S. 244, 250 (1968).

42. Once aware of the injunction, these "aiders and abettors" could be subject to civil and criminal contempt sanctions on the theory that they knowingly brought about the enjoined act. See Alemite Mfg. Corp. v. Staff, 42 F.2d 832, 833 (2d Cir. 1930) (person not a party to original proceeding may be punished for helping to bring about enjoined act of a party). 
pacity to endure such a self-imposed embargo surpasses that of the cartel nations. ${ }^{43}$

\section{Antitrust Jurisdiction Over Multiple-Nation Cartels}

Although extraterritorial price-fixing activities by private parties constitute per se violations of the antitrust laws, ${ }^{44}$ price fixing by foreign governments is actionable only if (1) the foreign governments and their instrumentalities constitute "persons" who can be sued under the antitrust laws; (2) the doctrines of sovereign immunity, act of state, and sovereign compulsion are unavailing; and (3) the restrictive practices have the requisite jurisdictional effect on United States foreign commerce. Despite these stringent requirements, the antitrust laws can reach multiple-nation cartels.

\section{A. Foreign Governments and Their Instrumentalities as "Persons"}

The Sherman Act imposes liability and creates a treble damage remedy for "persons." In Pfizer, Inc. v. India, ${ }^{46}$ the Supreme Court ruled that foreign nations are "persons" entitled to sue for treble damages under the antitrust laws. ${ }^{47}$ Consequently, foreign governments and their instrumen-

43. The impact of this embargo on the cartel countries, of course, would be diluted to the extent that non-cartel output is diverted to the United States from other consuming countries, which are then supplied by the cartel. This "displacement" phenomenon would depend on the market share of the non-cartel producers, the proportion of world output consumed in the United States, and the economic inefficiencies (particularly at the distribution stage) and logistical problems resulting from the realignment of supply relationships.

44. See supra note 6 .

45. See 15 U.S.C. $\$ 7$ (1976). "Persons" is defined to include "corporations and associations existing under or authorized by the laws of either the United States, the laws of any of the Territories, the laws of any State, or the laws of any foreign country." Id. The district court in $O P E C$ held that foreign governments are not persons who can be subject to antitrust prosecution. See International Ass'n of Machinists \& Aerospace Workers v. OPEC, 477 F. Supp. 553, 570 (C.D. Cal. 1979), aff'd on other grounds, 649 F.2d 1354, 1361-62 (9th Cir. 1981), cert. denied, 102 S. Ct. 1036 (1982). Two other courts in dictum have reached similar conclusions. See Hunt v. Mobil Oil Corp., 550 F.2d 68, 78 n.14 (2d Cir.), cert. denied, 434 U.S. 984 (1977); Interamerican Ref. Corp. v. Texaco Maracaibo, Inc., 307 F. Supp. 1291, 1298 (D. Del. 1970).

46. 434 U.S. 308 (1978).

47. The Pfizer Court reasoned that the denial of antitrust coverage to foreign governments (because of their foreign or sovereign attributes) would be fundamentally unfair and would frustrate the broad deterrent and compensatory goals of the antitrust laws. Id. at 314-15. The logic of this decision precludes any reading of "persons" that excludes foreign sovereign defendants. Even the criticisms leveled by the Pfizer dissenters buttress the case for subjecting foreign nations to antitrust liability. For example, in his dissent (joined by Justices Powell and Rehnquist), Chief Justice Burger argues that the Sherman Act's legislative history evinced Congress's intent to bar only those anticompetitive restraints affecting American imports. Id. at 324. Clearly, anticompetitive conduct by foreign governments would fall within this category. The Chief Justice also contended that the expansive reading of "persons" in Georgia v. Evans, 316 U.S. 159 (1942), which permitted domestic states to sue for treble damages, was distinguishable because the manipulation of the literal meaning of "persons" there was necessary to protect the intended beneficiaries of the Sherman Act-the American citizens on whose behalf the domestic state acts. Pfizer, 434 U.S. at 326 . Similarly, the applicability of the antitrust laws 
talities, ${ }^{48}$ as defendants, should not be allowed to elude the antitrust laws unless there is a countervailing policy of sufficient weight to overcome the strong presumption against implied exceptions to the antitrust laws. ${ }^{49}$

One overriding principle proffered by several commentators is the policy of fostering international comity. ${ }^{50}$ The principle of comity requires each nation as a matter of civility and respect to refrain from exercising extraterritorial jurisdiction where another foreign state has a stronger interest. By way of analogy to the Parker v. Brown ${ }^{51}$ line of cases, these commentators have argued that in the absence of an express legislative directive to the contrary, considerations of comity should prevent courts from construing the antitrust laws to cover foreign governmental conduct.

But reliance on this canon of statutory construction is misplaced in light of the Foreign Sovereign Immunities Act. Under the FSIA, the sovereign immunity defense-a doctrine traditionally grounded on notions of comity - cannot be claimed by government defendants whose challenged conduct is commercial in nature. ${ }^{52}$ Applicable to antitrust litigation, ${ }^{53}$ this

to restrictive trade practices of foreign governments would comport with Evan's consumer-oriented rationale. The refusal of the Supreme Court in Parker v. Brown, 317 U.S. 341 (1943), to broaden antitrust coverage to domestic state defendants does not undercut Evan's precedential force in this context. The troublesome factor in Parker-that the challenged state action benefitted at least one segment of the American public-is not present in antitrust suits against foreign governments.

48. The following policy analysis applies equally to both foreign governments and their instrumentalities. Two additional reasons, however, specifically favor antitrust coverage of foreign state instrumentalities. First, as a practical matter, foreign state commercial instrumentalities are tantamount to foreign corporations, which are expressly subject to the antitrust laws. See Outboard Marine Corp. v. Pezetel, 461 F. Supp. 384, 397-98 (D. Del. 1978) (antitrust laws applicable to non-corporate Polish government instrumentality). Second, exclusion of non-corporate foreign state instrumentalities would discriminate against capitalist governments participating in the commercial arena under the corporate guise. Id. at 397 .

49. In ruling that municipalities could be sued as "persons" under the antitrust laws, the Supreme Court in Lafayette v. Lousiana Power \& Light Co., 435 U.S. 389, 397 (1978), chose to indulge in this public policy analysis rather than simply to rely on Chattanooga Foundry \& Pipeworks v. Atlanta, 203 U.S. 390 (1906), which had ruled that muncipalities were "persons" entitled to bring treble damage suits. Thus far, only two policies have been deemed important enough to nullify the very strong presumption against implied exclusions from the antitrust laws. See Eastern R.R. Presidents Conference v. Noerr Motor Freight, 365 U.S. 127, 137-38 (1961) (policy of protecting First Amendment values and allowing persons unhampered access to public officials); Parker v. Brown, 317 U.S. 341, 350-52 (1943) (policy of promoting federalism).

50. See, e.g., Note, American Antitrust Liability of Foreign State Instrumentalities: A New Application of the Parker Doctrine, 11 CORNELL INT'L L.J. 305 (1978); Comment, supra note 12, at 604-09.

51. 317 U.S. 341,351 (1943) (holding domestic states exempt from antitrust laws on ground that principles of federalism preclude any inference of legislative intent to expose domestic state regulatory action to antitrust liability).

52. See infra pp. 778-79.

53. The House Report indicates that the jurisdictional features (the requirements of "direct effect," see infra note 58, and "substantial contacts," see supra note 30) of the commercial activity exception were not "intended to alter the application of the Sherman Antitrust Act . . . to any defendant." H.R. REP. NO. 1487, supra note 33 at 19, 1976 U.S. CODE CONG. \& AD. NEWS at 6618. If this exception were inapplicable to antitrust suits against foreign states, the House Report would not have discussed the relevance of its terms to foreign state antitrust defendants. See Outboard Marine Corp. v. Pezetel, 461 F. Supp. 384, 395 (D. Del. 1978) (citing legislative history for proposition that 
"commercial activity" exception reflects Congress' judgment as to when general considerations of comity should shield foreign state conduct from the antitrust laws. ${ }^{54}$ Accordingly, wholesale exclusion of foreign sovereign defendants from antitrust coverage on comity grounds would frustrate legislative intent.

\section{B. Sovereign Immunity}

The version of the "commercial activity" or "commercial dealing" exception most applicable to extraterritorial cartel activities withholds sovereign immunity when the government conduct at issue takes place "outside the territory of the United States in connection with a commercial activity of the foreign state elsewhere and . . . causes a direct effect in the United States." ${ }^{15}$ The exception therefore has three facets. The specific act under review must have been performed in connection with an activity or transaction $^{56}$ that is commercial in nature ${ }^{57}$ and that has had a direct effect on

commercial activity exception applies to foreign state antitrust defendants).

54. It has been argued that because the codified doctrine of sovereign immunity no longer gives adequate weight to traditional principles of comity, these considerations may be invoked to restrict the applicability of the antitrust laws to foreign sovereigns. See Comment, supra note 12, at 603 . But even if the commercial activity exception is more responsive to concerns of fairness to the private litigants than to comity considerations, it nevertheless reflects a legislative accomodation of these competing policies. This balance should not be circumvented by judicial efforts to construe the antitrust laws in a restrictive fashion.

55. 28 U.S.C. $§ 1605(a)(2)$ (1976). Section 1605(a)(2) also establishes two other commercial activity exceptions. The first clause of this provision withholds immunity where the lawsuit is based upon "a commercial activity carried on in the United States by the foreign state," that is, commercial activity that has substantial contact with the United States, see supra note 30 . The second clause bars a plea of immunity where the action is based on "an act performed in the United States in connection with a commercial activity of the foreign state elsewhere." As conceded in the House Report, H.R. REP. No. 1487, supra note 33, at 19, 1976 U.S. CODE CONG. \& AD. NEWS at 6618, the first clause essentially encompasses the second clause; commercial activity involving acts within the United States would generally meet the "substantial contacts" test of the first clause. Similarly, the first clause substantially overlaps with the third clause (which is quoted in the text). Incorporating a "minimum contacts" requirement, see infra note 58 , the third clause would provide an exclusive basis for jurisdiction only where the commercial activity involved displayed minimum, but not substantial, contacts with the United States. For analytical convenience, however, this Note will focus on the third clause of Section 1605(a)(2).

56. Neither judicial decisions nor legislative history shed any light on the meaning of the "in connection with" requirement. Two interpretations seem possible. A narrow construction suggests that the foreign government conduct in question must have a closer link to a commercial activity than to any governmental activity. If the challenged foreign state act (as distinct from the underlying activity) is itself classified as "commercial," (that is, an act that could be undertaken by a private individual, see infra note 57), it necessarily satisfies this restrictive view of the nexus requirement. If read literally, however, the "in connection with" phrase only requires the specific foreign state act to have a certain threshold nexus to a commercial activity. Under this construction, even a "governmental" foreign state act would fall within the commercial dealing exception if it exhibited the requisite ties to a commercial activity.

57. Aware of the difficuilties inherent in defining "commercial activity" in the abstract, Congress deliberately gave the judiciary wide latitude to shape the contours of this elusive concept. See H.R. REP. No. 1487, supra note 33, at 16, 1976 U.S. CODE CONG. \& AD. NEwS at 6615. But Congress did articulate certain guidelines. Section 1603(d), for example, makes clear that the nature of the activity-as distinct from its purpose-is the controlling factor. In addition, the legislative history indicates 


\section{United States foreign commerce. ${ }^{58}$}

Agreements by foreign governments to coordinate price and output strategies usually exhibit these three characteristics. ${ }^{59}$ Because the FSIA definition of commercial dealing covers any activity that a private person is capable of performing, such price-fixing agreements must be characterized as commercial acts. ${ }^{60}$ Indeed, it is typically private individuals rather

that the touchstone of commerciality is whether a private person is capable of engaging in the activity. See id. at 16, 1976 U.S. CODE CONG. \& AD. NEWS at 6615.

58. Since denial of immunity automatically invests the court with personal and subject matter jurisdiction over the foreign state defendant, Congress included implicit jurisdictional standards in each immunity exception. See id. at 12-13, 1976 U.S. CODE CONG. \& AD. NEWS at 6611-12. The "direct effect" provision embodies the jurisdictional requirement for the commercial activity exception. See Kahale \& Vega, Immunity and Jurisdiction: Toward a Uniform Body of Law in Actions Against Foreign States, 18 COLUM. J. TRANSNAT'L L. 211, 224-26 (1979). Both case law and legislative history indicate that the direct effects test must be applied in light of (1) the District of Columbia long-arm statute; (2) the subject matter jurisdiction principles of the RESTATEMENT (SECOND) OF FOREIGN RELATIONS LAW OF THE UNITED STATES $\$ 18$ (1965) (extraterritorial act on which jurisdiction based must have substantial, foreseeable and direct impact within United States); and (3) the due process requirement of minimum contacts. See Harris v. VAO Intourist, Moscow, 481 F. Supp. 1056 (E.D.N.Y. 1979); H.R. REP. NO. 1487, supra note 33, at 13-14, 19, 1976 U.S. CODE CONG. \& AD. NEWS at $6612,6618$.

59. Such agreements form the gravamen of the price-fixing offense. See United States v. SoconyVacuum Oil Co., 310 U.S. 150, $224 \mathrm{n} .59$ (1940) (dictum) (even if ineffective, conspiracy to fix prices is a per se violation of $\S 1$ ). Most significantly, the per se ban against price fixing does not implicate the right of any enterprise (including a foreign government in its proprietary capacity) unilaterally to raise prices or restrict output. See Berkey Photo v. Eastman Kodak Co., 603 F.2d 263, 274-75 n.12 (2d Cir. 1979) (lawful monopolist may charge as high a price as it desires). An examination of the applicability of the commercial activity exception to foreign government cartel participants or sponsors must therefore focus on the price fixing agreement itself; the nature of the particular mechanism used by each government cartel member to raise prices or reduce output (e.g., taxes and royalties) is irrelevant for purposes of the commercial activity exception. Contra Comment, supra note 12, at 591-92.

60. To be sure, the purpose of a price fixing agreement among foreign governments may be to enhance each country's fiexibility in setting national price and output policies-an arguably governmental activity. Nevertheless, even if endowed with such a public purpose, the nature of the pricefixing conspiracy remains unaffected. In International Ass'n of Machinists \& Aerospace Workers v. OPEC, 477 F. Supp. 553 (C.D. Cal. 1979), aff'd on other grounds, 649 F.2d 1354, 1361-62 (9th Cir. 1981), cert. denied, 102 S. Ct. 1036 (1982), the district court reached the contrary conclusion that the price-fixing activities of the OPEC nations are governmental in nature and hence protected by the sovereign immunity defense. Its argument can be analytically refined to the following three propositions: (1) a government's power to control the development of its natural resources is an intrinsic attribute of sovereignty; (2) establishing the conditions for the production and sale of its resources is an exercise of this sovereign power and, as such, is governmental in nature; and (3) the governmental character of this regulatory act-the setting of price and production levels-is not altered when undertaken in concert with similar initiatives by other foreign governments. This analysis is faulty for several reasons. While difficult to deny, the first proposition merely establishes that the regulation of natural resources serves a governmental purpose. The second proposition fails to recognize that the specific means used to accomplish this public purpose may be either commercial or governmental in nature. Most importantly, the third proposition fails to grasp the difference between the unilateral act of determining price and production levels and the multilateral act of coordinating production and marketing strategies. The OPEC court's efforts to characterize the former act as governmental were wholly misdirected as the latter act formed the core of the antitrust cause of action.

Though the Ninth Circuit did not formally reach the sovereign immunity issue, it seemed to acknowledge that the district judge had improperly considered the purpose behind OPEC's price fixing (control of natural resources) in declaring these activities to be governmental. Indeed, the Ninth Circuit chose to dispose of the case on act of state rather than sovereign immunity grounds precisely because the former doctrine permitted consideration of the governmental purpose of OPEC's conduct. 
than foreign states that indulge in this anticompetitive practice. Since the act of price collusion is commercial in nature, the "in connection with" requirement is also clearly satisfied, even if the price fixing is linked to some governmental activity. ${ }^{61}$ Finally, most multiple-nation cartels also have the requisite "direct effect." This FSIA criterion requires that the defendant state's activities have a substantial and foreseeable impact on United States commerce (a subject matter jurisdiction test) and satisfy the due process standard of minimum contacts (a personal jurisdiction test). In light of the substantial aggregate market shares typically enjoyed by these international cartels, their impact on the United States economy is usually both appreciable and foreseeable. Furthermore, a cartelist's contacts with the United States-its United States sales and the harmful consequences its price-fixing activities have in the United States-are sufficient to satisfy the personal jurisdiction requisites of the "direct effect" provision. ${ }^{62}$

\section{Act of State Doctrine}

The act of state doctrine is a principle of federal common law that in certain circumstances requires United States courts to presume the validity of acts committed by foreign states within their own territority. ${ }^{63}$ Arising

649 F.2d at $1358,1360$.

61. Even if price fixing were not regarded as inherently commercial, the requirements of commerciality and nexus (broadly construed) would still be satisfied because of the close link between price fixing and the sale of the cartelized goods. The legislative history expressly refers to the sale of a product as a commercial activity. See H.R. REP. NO. 1487, supra note 33, at 16, 1976 U.S. CODE CONG. \& AD. NEWS at 6615. Furthermore, the act of price fixing, viewed as a means of establishing the terms of sale, meets the broad version of the "in connection with" standard. See supra note 56.

62. These U.S. contacts clearly satisfy the Supreme Court's most recent formulation of the minimum contacts standard articulated in World-Wide Volkswagen Corp. v. Woodson, 444 U.S. 286, 297 (1980) ("[D]efendant's conduct and connection with the forum State [must be] such that he should reasonably anticipate being haled into court there.") See id. at 297-98 ("[F]orum State does not exceed its powers under the Due Process Clause if it asserts personal jurisdiction over a corporation that delivers its products into the stream of commerce with the expectation that they will be purchased by consumers in the forum State.") (emphasis added); Note, Direct Effect Jurisdiction Under the Foreign Sovereign Immunities Act of 1976, 13 N.Y.U. J. INT'L L. \& PoL. 571, 603 (1981) (intended forum effects of conduct under review satisfies World-Wide Volkswagen). The cartelist's connections with the United States also fulfill the "tortious injury" and "transaction of business" provisions of the District of Columbia long-arm statute. See supra note 58. Under the "tortious injury" provision, jurisdiction can be asserted over a person whose conduct outside the forum produces tortious consequences within the forum, provided "he regularly does or solicits business, . . . or derives substantial revenue from goods used or consumed, . . . in the District of Columbia." D.C. CODE ANN. § 13423(a)(4) (1973). This jurisdictional provision is plainly applicable to multiple-nation cartel participants since they avail themselves of the benefits of having their products marketed within the United States. The District of Columbia "transaction of business" provision also provides a jurisdictional predicate if interpreted to apply to out-of-state acts that produce foreseeable effects within the forum. Cf. Note, The Foreign Sovereign Immunities Act of 1976: Direct Effects and Minimum Contacts, 14 CORNELL INT'L L.J. 97, 106 (1981) (courts in other jurisdictions have so construed similar "transacting business" tests).

63. See Banco Nacional de Cuba v. Sabbatino, 376 U.S. 398 (1964). When applicable, the act of state doctrine supersedes ordinary choice of law rules in two ways. First, the doctrine designates a 
principally from separation of powers considerations, the act of state doctrine primarily reflects a policy of judicial abstention to be invoked when adjudication would unduly impair executive foreign policy. ${ }^{64}$

According to the landmark case, Banco Nacional de Cuba v. Sabbatino, ${ }^{65}$ act of state analysis entails a two-tier inquiry. Under the first tier, the sovereign act at issue must meet three threshold requirements: ${ }^{.6}$ the act must be public, consummated within the territory of the foreign sovereign, and committed by a recognized foreign power. Multiple-nation cartels do not satisfy this first tier of the act of state doctrine. The pricefixing activities of foreign governments do not constitute "public acts" if the concept of "public" excludes commercial sovereign conduct." In addi-

particular foreign state act as the rule of decision regardless of which law (domestic state or federal law, international law as incorporated into United States law, or the foreign state's law) is favored under normal choice of law methodology. Second, the act of state doctrine prevents United States courts from refusing to recognize the validity of the foreign state act on grounds of public policy. See Comment, supra note 12 , at $629-30$.

64. See Banco Nacional de Cuba v. Sabbatino, 376 U.S. 398, 427-28 (1964) (act of state doctrine designed to achieve "proper distribution of functions between the judicial and political branches"); see also First National City Bank v. Banco Nacional de Cuba, 406 U.S. 759, 787-88 (1972) (Brennan, J., dissenting) (characterizing act of state doctrine as political question doctrine); International Ass'n of Machinists \& Aerospace Workers v. OPEC, 649 F.2d 1354, 1358-59 (9th Cir. 1981) (same), cert. denied, 102 S. Ct. 1036 (1982).

65. 376 U.S. 398 (1964).

66. These preliminary criteria are vestiges of the historical formulation of the act of state doctrine, which was rooted in traditional notions of territorial sovereignty. See Underhill v. Hernandez, 168 U.S. 250 (1897). In retreating from this unduly broad, inflexible rule, Sabbatino did not indicate whether these criteria should be viewed as threshold requirements or merely as factors to be considered in the separation of powers inquiry (the second tier of the act of state doctrine). Subsequent cases have treated the second and third criteria as prerequisites for act of state immunity. See, e.g., Alfred Dunhill of London, Inc. v. Republic of Cuba, 425 U.S. 682, 694 (1976) (defendant's refusal to discharge quasi-contractual obligation did not amount to "public act of those with authority to exercise sovereign powers"); United Bank Ltd. v. Cosmic Int'l, Inc., 542 F.2d 868 (2d Cir. 1976) (act of state treatment denied to sovereign expropriation of property whose situs was in United States). The status of the "public act" (that is, a governmental as distinct from a commercial act) criterion is unclear. See infra note 67. Even as a mere factor in the second tier of the act of state analysis, this criterion may be so weighty that it effectively operates as a threshold requirement. See Dunhill, 425 U.S. at 703-04 (according to plurality, second tier of Sabbatino factors supports broad commercial activity exception to act of state doctrine).

67. See Alfred Dunhill of London, Inc. v. Republic of Cuba, 425 U.S. 682, 693, 696 (1976) (plurality opinion) (carving out commercial activity exception based on "nature" test). Thus far, the Ninth Circuit's opinion in $O P E C$ is the only decision to address whether foreign state commercial conduct deserves act of state treatment in light of the FSIA commercial activity exception. International Ass'n of Machinists \& Aerospace Workers v. OPEC, 649 F.2d 1354, 1359-61 (9th Cir. 1981), cert. denied, 102 S. Ct. 1036 (1982). There, the Ninth Circuit reasoned that OPEC price fixing served important public interests (that is, a governmental purpose) and thus did not fall within the category of purely commercial activities refused judicial deference by the Dunhill plurality. Because the act of state doctrine, unlike the sovereign immunity doctrine, is designed to avoid judicial intrusion in sensitive foreign policy matters, and because sovereign motivations provide one indication of the political sensitivity of the underlying dispute, the OPEC court argued that the FSIA's focus on the nature of the foreign government act does not preclude consideration of the sovereign's purpose in the act of state context. As support for this proposition, the Ninth Circuit made two misleading references to FSIA legislative history. While correctly observing that "the [House] Committee found it unnecessary to address the act of state doctrine," 649 F.2d at 1359, the Ninth Circuit neglected to convey the Committee's reason for doing so: its belief that the courts would not subvert the FSIA commercial 
tion, many multiple-nation cartels may not meet the requirement of territoriality because their pervasive extraterritorial impact renders them more analogous to acts of state that occur partly within the United States than to acts of state performed wholly within the foreign country's jurisdiction. ${ }^{68}$ Specifically, these cartels breach the territoriality requirement because they unlawfully appropriate property within the United States (our money).$^{69}$ The third preliminary test-that the act be committed by a recognized sovereign power-will prove fatal to a foreign state instrumentality that participated in a cartel without express authorization from its government. ${ }^{70}$

Even if foreign government involvement in a multiple-nation cartel meets these three threshold tests, act of state treatment must be denied under the second tier of this doctrine in most cases. Under this second tier, a court must determine whether it has sufficient competence within our system of separation of powers to adjudicate the particular kind of sovereign act in question. In assessing judicial competence to adjudicate expropriation claims under international law, the Sabbatino Court weighed the following factors: (1) the degree of international consensus on the applicable international law (or the availability of standards in a treaty or other

activity exception by applying the act of state doctrine to foreign state commercial conduct. H.R. REP. No. 1487, supra note 33, at 20 n.1, 1976 U.S. CODE CONG. \& AD. NEWS at 6619 n.1. The OPEC court also improperly referred to the section-by-section analysis that accompanied the 1973 version of the FSIA-a document that was expressly superseded by the section-by-section analysis for the enacted version of the FSIA. Id. at 12, 1976 U.S. CODE CONG. \& AD. NEWS at 6611. In the final analysis, however, whether the "public act" requirement should turn on the purpose or nature of the foreign government's act is probably academic. Even if foreign state conduct that is commercial in nature but governmental in purpose does not satisfy the "public act" requirement, its governmental purpose will be given ample weight in the court's consideration of the judicial abstention doctrine. See infra pp. 786-88.

68. There is virtually no case law on whether a government act and its effect should be blended together for purposes of act of state analysis. One plausible approach would be to treat the effect as part of the act of state where it represents a constituent element of the alleged offense. CF. RESTATEMENT (SECOND) OF FOREIGN RELATIONS LAW OF THE UNITED STATES § 18 (1965) (extraterritorial subject matter jurisdiction may be based on effects of extraterritorial act if those effects formed constituent element of offense charged). This proposal would conform with the manner in which the territoriality requirement is applied in expropriation cases, virtually the only category of act of state cases in which the issue arises. There, territoriality is determined solely by reference to the situs of the expropriated property. See, e.g., United Bank Ltd. v. Cosmic Int'l, Inc., 542 F.2d 868, 872-73 (2d Cir. 1976); Republic of Iraq v. First Nat'l City Bank, 353 F.2d 47, 51 (2d Cir. 1965), cert. denied, 382 U.S. 1027 (1966). The "constituent element" concept would not demand a different result, as the indirect financial impact on the United States owners of the expropriated foreign property is not part of the alleged violation. By contrast, the governmental act of price fixing would be ineligible for act of state deference under the proposed rule; because the impact of price fixing is an integral part of the antitrust infraction, such government conduct would be infected with extraterritorial dimensions.

69. See RESTATEMENT (SECOND) OF FOREIGN RELATIONS LAW OF THE UNITED STATES § 43 comment $\mathrm{c}$ (1965) (act of state defense unavailable where government act "affects property within the territory of another state . . . and the acting state purports to execute it by reducing the property to possession in a manner which is unlawful under the law of the territorial state").

70. See Alfred Dunhill of London, Inc. v. Republic of Cuba, 425 U.S. 682, 695 (1976) (act of Cuban instrumentality not elevated to "act of state" status because of absence of authorizing "statute, decree, order, or resolution of the Cuban Government"). 
agreement) $;{ }^{71}$ (2) the ability of the courts to aid the executive in providing a fair and adequate remedy for the aggrieved United States citizens; ${ }^{72}$ (3) the likelihood of disagreement between the executive and the judiciary over the disposition of the case; ${ }^{73}$ and (4) the danger that adjudication would have severe foreign relations repercussions. ${ }^{74}$

These Sabbatino factors do not furnish a sufficient basis for shielding multiple-nation cartels from antitrust assault. First, unlike the murky international law at issue in Sabbatino, the per se rule against price fixing does not lack clarity. ${ }^{75}$ Second, in contrast to their inability to fashion an effective remedy in expropriation cases, the courts can enhance the ability of the executive to deal with multiple-nation cartels. ${ }^{76}$ Third, in view of the clarity of the per se rule against price fixing, it is not likely that the views of the judiciary and the executive will differ as to the legality of multiple-nation cartels. To be sure, interbranch disagreement may arise over the propriety of exercising jurisdiction. ${ }^{77}$ But the ability and willingness of the courts to entertain the views of the executive would minimize such intragovernmental discord. ${ }^{78}$ Finally, although adjudication of multi-

71. Banco Nacional de Cuba v. Sabbatino, 376 U.S. 398, 428 (1964).

72. Id. at 432 (probability that adjudication would "seriously interfere with negotiations being carried on by the Executive Branch and . . . prevent or render less favorable the terms of the agreement that could otherwise be reached").

73. Id. at $432-33$ (examining possibility of conflict between judiciary and executive as to content of international law on expropriation).

74. Id. at 428. Placing greater weight on criteria (2) and (4), the plurality in Alfred Dunhill of London, Inc. v. Republic of Cuba, 425 U.S. 682, 705-06 n.18 (1976) refined these four Sabbatino criteria into a more coherent formula. In their view, act of state deference is not warranted where the benefits of adjudication outweigh its adverse foreign relations impact. See also Industrial Inv. Dev. Corp. v. Mitsui \& Co., 594 F.2d 48, 53 (5th Cir. 1979) (act of state defense should be recognized in antitrust cases only where "special political factors . . . outbalance this country's legitimate interest in regulating anticompetitive activity both here and abroad").

75. Contrary to the views of the Ninth Circuit in the OPEC case, Sabbatino does not suggest that the availability of well-settled international legal principles is a factor to be considered in act of state cases where United States federal law governs. Indeed, that factor was relevant in Sabbatino only because the specific act of state under review-an expropriation-was challenged under international law, not domestic law. In short, this Sabbatino factor is an application of the "political question" principle that the standards for reviewing sovereign acts be discernible. Cf. Baker v. Carr, 369 U.S. 186,217 (1962) (one factor in political question analysis is "lack of judicially discoverable and manageable standards for resolving [the question at issue]"). In any event, in view of the price-fixing prohibition unanimously adopted by the United Nations General Assembly, the United States antitrust laws' aversion to price collusion now enjoys a signficant measure of international consensus. The Set of Multilaterally Agreed Equitable Principles and Rules for the Control of Restrictive Business Practices, G.A. Res. 35/63, U.N. Doc. A/Res./35/63 (1980) (subsection D(3) forbids such cartel mechanisms as price-fixing agreements that "limit access to markets or otherwise unduly restrain competition"). But see Oesterle, United Nations Conference on Restrictive Business Practices, 14 CORNELL INT'L L.J. 1 (1981) (subsection D(3), which is directed against "enterprises," may not reach central foreign government cartelists).

76. See supra pp. 768-76.

77. See infra pp. 786-88.

78. In First National City Bank v. Banco Nacional de Cuba, 406 U.S. 759 (1972), six Justices in various opinions concluded that the judiciary cannot be bound by the executive's suggestion as to the applicability of the act of state doctrine. However, First National City Bank does not bar courts from 
ple-nation price-fixing conspiracies might implicate policies deemed important by the foreign government participants, this Sabbatino factor triggers the act of state defense only if the court finds that the resulting injury to foreign relations outweighs the injury to those public and private interests protected by the antitrust laws. ${ }^{79}$

\section{Sovereign Compulsion Doctrine}

Though its contours have not yet been fully developed ${ }^{80}$ the doctrine of sovereign compulsion is designed to immunize private conduct undertaken in compliance with a foreign state directive. ${ }^{81}$ While a literal application of this doctrine would appear to exculpate coerced private-cartel participants, a careful analysis of its two divergent policy underpinnings argues against its availability in these circumstances. ${ }^{82}$ As originally conceived,

according substantial weight to the views of the executive. See Comment, supra note 12, at 648 .

79. For several reasons, this Sabbatino criterion should not dictate act of state treatment in most multiple-nation cartel cases. First, unlike the expropriation challenged in Sabbatino, where the only U.S. interests at stake were those of the private plaintiffs, price fixing by multiple-nation cartels has substantial extraterritorial effects that jeopardize important United States public interests. Second, the ability of the courts to decline jurisdiction on comity or foreign relations grounds under the judicial abstention doctrine will minimize the disruption in foreign relations. Third, the inapplicability of the act of state doctrine to foreign government acts that partially occur within the United States indicates that the possibility that adjudication would antagonize foreign governments is not dispositive. On many occasions, United States courts have condemned "transnational" acts of state on public policy grounds, despite the consequent affront to the foreign state. See, e.g., United Bank Ltd. v. Cosmic Int'l, Inc., 542 F.2d 868 (2d Cir. 1976) (refusing on public policy grounds to allow Pakistani government to expropriate debt with United States situs that was owed to previous owners of confiscated factory). Finally, it should be noted that the balancing process undertaken in act of state analysis closely resembles that contemplated by the judicial abstention doctrine (though the latter has a somewhat greater case by case orientation). See infra pp. 786-88. Therefore, the reasons favoring judicial intervention under the abstention doctrine in some multiple-nation cartel cases are equally pertinent here.

80. Based largely on dicta and legal commentary, the sovereign compulsion defense has been successfully interposed in only one case. See Interamerican Ref. Corp. v. Texas Maracaibo, Inc., 307 F. Supp. 1291, 1296-99 (D. Del. 1970).

81. The sovereign compulsion defense has been rejected where the private defendant's anticompetitive conduct was merely encouraged by the foreign government, see United States v. Watchmakers of Switz. Information Center, 1963 Trade Cas. (CGH) I 70,600, at 77,456-57 (S.D.N.Y. 1962), modified, 1965 Trade Cas. II 71,352 (S.D.N.Y. 1965), or permitted pursuant to a grant of discretionary authority, see Continental Ore Co. v. Union Carbide \& Carbon Corp., 370 U.S. 690, 706-07 (1962). Cf. Timberlane Lumber Co. v. Bank of America, 549 F.2d 597, 607 (9th Cir. 1976) (dictum) (even compelled private action should not be sheltered by the sovereign compulsion defense in some circumstances); Sabre Shipping Corp. v. American President Lines, 285 F. Supp 949, 954 (S.D.N.Y. 1968) (dictum) (same).

82. The sovereign compulsion issue should be distinguished from the issue of whether the specific acts of the compelled private party amount to an antitrust violation. Resolution of this latter issue will, of course, depend on the role played by the private party in the cartel scheme. Clearly, the antitrust laws will be infringed where the private party actually contributes to the cartel agreement-the core of the antitrust infraction. Culpability is problematic, however, where the compelled private party merely implements the terms of a cartel agreement to which it contributed nothing.

Policy considerations favor the imposition of liability only if the private party retains some of the cartel profits (or otherwise receives remunerative inducements to cooperate in the cartel scheme). If no direct or indirect benefit is obtained, the private party would have a strong incentive to resist the government's cartel plan. See supra note 36 . The private cartelist should shoulder the burden of 
the sovereign compulsion defense functions as a corollary to the act of state principle; it treats private conduct compelled by a foreign state as tantamount to an act of state and hence immune from judicial scrutiny ${ }^{83}$ Under this view, the availability of the compulsion defense should turn on whether the act of state defense could have been invoked by the commanding foreign state had it perpetrated the act in question. Accordingly, since the act of state defense is not available to foreign state cartel members, this version of the sovereign compulsion defense cannot exonerate coerced private-cartel members.

Several courts and commentators, however, have contended that the unfairness of holding the private defendant liable for involuntary conduct actually supplies the primary justification for the doctrine. ${ }^{84}$ If rooted in such notions of fairness, the compulsion doctrine has been effectively supplanted by the judicial abstention doctrine, which contemplates a balancing of the interests of the coerced private party as well as the interests of the commanding state against the United States interests injured by the compelled conduct of the private party. As will be seen in Part III, the United States interest against price fixing should always prevail. ${ }^{85}$

\section{E. Effects Doctrine}

The effects doctrine, which originated in the landmark Alcoa case, ${ }^{86}$ extends the reach of the antitrust laws to extraterritorial conduct that has some effect on United States trade. ${ }^{87}$ This doctrine is coextensive with the

persuasion on the elusive issue of whether it benefited from the price fixing for two reasons. First, it has superior access to the relevant data. Second, the costs of systematically erring in favor of no liability-a finding of no monopoly profit retention-exceed the costs of systematically erring in the opposite direction. Erroneous findings of no liability will significantly reduce the incentive of private companies to resist the cartelizing edicts of their host governments. On the other hand, erroneous findings of liability, by bolstering the private parties' incentive to resist, will further curb the incidence of cartelization-a benefit that will at least partially offset the unfairness of subjecting innocent parties to antitrust sanctions.

83. This was the principal justification articulated by the district court in Interamerican Ref. Corp. v. Texaco Maracaibo, Inc., 307 F. Supp. 1291 (D. Del. 1970). The court was also swayed by fairness considerations, since, in its view, the private defendants had "no choice but to obey." Id. at 1298.

84. See, e.g., Mannington Mills, Inc. v. Congoleum Corp. 595 F.2d 1287, 1293 (3d Cir. 1979); Note, Foreign Sovereign Compulsion in American Antitrust Law, 33 STAN. L. REV. 131, 137-153 (1980).

85. See infra TAN 93-95; ANTITRUST DIVISION, U.S. DEP’T OF JUSTICE, ANTITRUST GUIDE FOR INTERNATIONAL OPERATIONS 55 (1977) (suggesting that balancing of comity interests may support denial of compulsion defense to private cartel participants).

86. United States v. Aluminum Co. of America, 148 F.2d 416 (2d Cir. 1945).

87. See W. FUGATE, supra note 7, at 73-75 (discussing various judicial expressions of effects test). Under the Alcoa formulation, extraterritorial conduct by non-nationals would not fall within the jurisdictional perimeter of the antitrust laws unless such conduct was intended to affect and actually affected U.S. foreign commerce. 148 F.2d at 443-44. But see Zenith Radio Corp. v. Matsushita Elec. Indus. Co., 494 F. Supp. 1161, 1189 n.65 (E.D. Pa. 1980) (noting that subsequent cases have recognized jurisdiction based on actual effects alone on theory that alien defendant intended the foreseeable 
subject matter jurisdiction component of the "direct effect" provision in the FSIA commercial activity exception. ${ }^{88}$ Accordingly, under the effects test, multiple-nation cartels generally fall within the ambit of the antitrust laws for the very reasons that they have a "direct effect" in the United States. ${ }^{89}$

\section{Occasions for the Exercise of Jurisdiction Over Multiple-Nation Cartels}

Dissatisfied with the "effects" test, several courts have recently held that considerations of comity and foreign relations must be taken into account before extraterritorial antitrust jurisdiction is assserted. ${ }^{90}$ This "judicial abstention" doctrine would appear to permit adjudication involving a multiple-nation cartel upon an independent determination that (1) the detrimental impact of the cartel on United States commerce outweighs the interests of the foreign states and any coerced private participants ${ }^{91}$ and (2) the benefits of antitrust enforcement (discounted by the probability of unenforceability) overshadow any adverse foreign relations impact. ${ }^{92}$

consequences of his actions). While perhaps still dispositive of the existence of subject matter jurisdiction, the effects test does not govern the determination as to whether such jurisdiction should be exercised. Rather, the effects doctrine has been incorporated into a broader analysis emphasizing considerations of comity and foreign relations. See infra pp. 786-88 (judicial abstention doctrine).

88. See H.R. REP. NO. 1487, supra note 33, at 5, 1976 U.S. CODE CONG. \& AD. NEWS at 6618 ("direct effect" not intended to alter antitrust case law identifying effect necessary to sustain extraterritorial jurisdiction).

89. See supra p. 780.

90. Thus far, three courts have embraced this balancing approach. See Mannington Mills, Inc. v. Congoleum Corp., 595 F.2d 1287, 1297 (3d Cir. 1979); Timberlane Lumber Co. v. Bank of America, 549 F.2d 597, 614 (9th Cir. 1976); Dominicus Americana Bohio v. Gulf \& W. Indus., 473 F. Supp. 680,687 (S.D.N.Y. 1979). The Mannington Mills calculus, which is quite similar to that profferred by the Timberlane court, includes the following variables:

1. Degree of conflict with foreign law or policy;

2. Nationality of the parties;

3. Relative importance of the alleged violation of conduct here compared to that abroad;

4. Availability of a remedy abroad and pendency of litigation there;

5. Existence of intent to harm or affect American commerce and its foreseeability;

6. Possible effect upon foreign relations if the court exercises jurisdiction and grants relief;

7. If relief is granted, whether a party will be placed in the position of being forced to perform an act illegal in either country or be under conflicting requirements by both countries;

8. Whether the court can make its order effective;

9. Whether an order for relief would be acceptable in this country if made by the forcign nation under similar circumstances;

10. Whether a treaty with the affected nations addresses the issue.

91. This aspect of the judicial abstention doctrine is based on criteria $1,2,3,5,7$, and 9 in the Mannington Mills formulation. See supra note 90 . See also Timberlane Lumber Co. v. Bank of America, 549 F.2d 597, 614-15 (9th Cir. 1976) (comity/foreign relations inquiry necessitates determination as to whether "contacts and interests" of United States sufficiently preponderate over those of foreign states involved to warrant assertion of jurisdiction).

92. This aspect of the judicial abstention doctrine is based on criteria 3,6 , and 8 in the Mannington Mills formulation. See supra note 90. See also Timberlane Lumber Co. v. Bank of America, 549 F.2d 597, 614 (9th Cir. 1976) (balancing requires assessment of "degree of conflict" to be precipitated 
In making the first determination involved in applying the abstention doctrine, the courts should adopt the presumption that the United States interest against price fixing always prevails. As the courts have recognized on countless occasions, United States public policy condemns price-fixing conspiracies with special vehemence. ${ }^{93}$ To be sure, the foreign governments involved in multiple-nation cartels, particularly developing countries, may have a significant interest in securing additional revenues to fuel their economic growth. But there are no objective criteria to weigh these countervailing interests. Moreover, even if courts were competent to balance these interests, they could not fashion appropriate remedies in cases in which the weighing calculus favors some sort of compromise. For example, the courts could not condition the legality of the cartel on the "reasonableness" of its prices. ${ }^{94}$ Accordingly, the judiciary should rely on the executive to identify those rare situations when our deep-seated preference for competition should give way to the interests of foreign governments (and coerced private cartelists). By negotiating commodity agreements, the executive, unlike the judiciary, can achieve an accomodation responsive to the more pressing interests of each side.

The United States interest against price fixing also should not give way to the supposed unfairness of subjecting the genuinely coerced private cartelist to inconsistent legal obligations. Admittedly, if the coerced firm is subjected to United States antitrust jurisdiction, the foreign government may retaliate by denying the firm access to its domestic markets or even by confiscating the firm's property. Nevertheless, as has been demonstrated, ${ }^{95}$ the very harshness of these consequences will galvanize private cartelists into resisting the directives of the foreign state, possibly resulting in their rescission. In any event, the costs of permitting cartels to operate with antitrust immunity overshadows the occasional injustice to a truly coerced private cartelist.

The next inquiry required by the judicial abstention doctrine-whether the benefits of antitrust enforcement override the potential international repercussions of asserting jurisdiction-can be quite complex and must be conducted on a case by case basis. In determining the antitrust benefits of imputing liability to foreign government cartelists, the court would have to

by exercise of jurisdiction). The judicial abstention doctrine appears to warrant forbearance where the cartel and the executive have concluded some form of international commodity agreement. Criteria 4, 6, and 10 in the Mannington Mills formulation support this proposition. See supra note 90 . If negotiations with the cartel are in progress, the court should defer consideration of the abstention issue pending completion of these discussions, to avoid impairing the executive's negotiating efforts.

93. See, e.g., United States v. Socony-Vacuum Oil Co., 310 U.S. 150, 218 (1940); United States v. Trenton Potteries Co., 273 U.S. 392, 397 (1927).

94. See supra note 8.

95. See supra p. 769. 
assess the extent to which sanctions could be enforced. As for the benefits of attaching liability to coerced private cartelists, the court would have to appraise the likelihood that these companies could successfully resist the demands of their host governments. In weighing the other half of the equation-the potential foreign relations impact of adjudication, the court must evaluate a variety of factors, which, while peculiar to each case, must reflect political reality. Foremost among these factors would be the likelihood and nature of retaliatory measures government cartel members might take and the extent to which the allegiance of the cartel countries would shift to the detriment of United States national security interests. ${ }^{96}$

\section{Delegation to the Executive}

In suits against multiple-nation cartels in which central foreign governments are actively involved, the courts are likely to be extremely reticent about undertaking this balancing process alone-and with good reason. Appraising the potential foreign relations impact of adjudication as well as the enforceability and benefits of antitrust sanctions clearly lies beyond the realm of judicial competence. Courts lack the fact-finding capacity to assess the myriad factors that bear upon these concerns. The procedural and evidentiary constraints surrounding the adjudicative process detract further from the judiciary's suitability for this task. Moreover, even if the judiciary could assess accurately the competing factors included in the judicial abstention analysis, ${ }^{97}$ it lacks the institutional competence to identify the appropriate trade-off between them.

Handicapped by these institutional shortcomings in adjudicating cartel

96. The OPEC cartel exemplifies the minority of situations in which the undesirable consequences of antitrust prosecution far outweigh any benefits to be derived. The reasons for antitrust paralysis against OPEC, however, would not apply to most multiple-nation cartels. First, most cartels do not control a product that, like oil, is indispensable to the United States economy. Second, many cartel countries, particularly the less developed ones, would not be in a position to take retaliatory action against the United States because they are more dependent on United States economic assistance. See Varon \& Takeuchi, Developing Countries and Non-Fuel Minerals, 52 FOREIGN AFF. 497, 509 (1974). Third, most cartels operate in areas of the world where United States national security interests are less pressing. Fourth, there is no reason to expect consumer governments and the private parties involved to capitulate to the price demands of an incipient cartel, as occurred in the OPEC situation. See Krasner, Oil is the Exception, 14 FOREIGN POL. 68, 77-78 (1974). Fifth, in contrast to OPEC, most cartels would lack the political, cultural, and religious bonds that foster solidarity among their members-a crucial ingredient for successful price fixing. See Mikesell, More Third World Cartels Ahead? CHALLENGE, November/December 1974, at 24, 27-28. Sixth, most cartels would not have a member (such as Saudi Arabia in the OPEC cartel) willing to accommodate a moderate degree of price chiseling by accepting a reduction in its market share. Seventh, relative to oil, most other cartelized products would be more vulnerable to the use of substitutes (as well as to the use of stockpiles and recycling techniques if the cartelized product is a raw material commodity). See Varon \& Takeuchi, supra, at 505-06.

97. For example, only the executive has the expertise necessary to determine the degree of risk to United States foreign relations that should be tolerated to achieve certain benefits from antitrust enforcement. 
cases in which central foreign governments play a major role, the courts could seek refuge in the judicial abstention doctrine or else solicit and accord virtually conclusive weight to the views of the executive. Neither approach is desirable. Automatic invocation of the judicial abstention doctrine would deprive the United States of the deterrent benefits of the antitrust laws in cartel cases where these benefits eclipse the probable adverse international repercussions. Straightforward implementation of the executive's recommendations would probably produce satisfactory results. Even better results, however, could be achieved if Congress delegated to the executive the authority to grant antitrust exemptions to any multiple-nation cartel where considerations of comity or foreign policy override the benefits of antitrust enforcement. ${ }^{98}$ As part of its delegated power, the executive should be given broad discretion to condition the exemption in any way consistent with United States consumer welfare. Under this approach, government as well as private cartelists (or prospective cartelists) could petition for antitrust immunity, even if no suit has been brought against them.

This proposed reallocation of "jurisdictional" power has two salient virtues. First, it draws upon the respective institutional strengths of the executive and the judiciary. As chief architect of United States foreign policy, the executive has a superior grasp of the international ramifications of adjudication. On the other hand, the courts-with their greater solicitude for principled decisionmaking and procedural regularity-offer the more appropriate forum for determining whether defendants have in fact breached the per se rule against price fixing.

Second, this arrangement would enable the executive to control the timing of negotiations and hence to maximize the value of any concessions offered for antitrust immunity. Under the present system, if a multiplenation cartel case arises at an inopportune time for negotiations, the court's consideration of the judicial abstention issue would confront the executive with a Hobson's choice: either initiate negotiations under unfa-

98. This proposal does not run counter to Congress' efforts to transfer responsibility over sovereign immunity determinations from the executive to the judiciary. See H.R. REP. No. 1487, supra note 33, at 7, 1976 U.S. CODE CONG. \& AD. NEWS at 6605-06. That transfer of authority was intended to insulate the resolution of "ordinary legal disputes" from extraneous diplomatic influences that previously afflicted the executive's practice of submitting suggestions on the immunity issue. Id. In contrast to the ordinary legal dispute, however, multiple-nation cartel cases unavoidably involve significant foreign policy and comity concerns that must be taken into account. Furthermore, the proposal urged here does not derogate from the power of the courts to determine the availability of the sovereign immunity defense in these cases. Finally, in an analogous situation, Congress took action similar to that proposed here; it empowered the executive to suspend on grounds of foreign policy the operation of the Hickenlooper Amendment (which essentially forbids resort to the act of state doctrine in certain expropriation cases where international law has been breached). See 22 U.S.C. $\$ 2370($ e)(2) (1976). 
vorable circumstances ${ }^{99}$ or recommend to the court one of the two possible dispositions of the judicial abstention issue-assertion or relinquishment of jurisdiction. The latter "all or nothing" approach is disadvantageous for two reasons. First, it forces the executive to endorse publicly one of the two polar viewpoints at an inappropriate time. Second, either resolution of the judicial abstention issue is generally less desirable than the compromise solution attainable through negotiations under non-adverse circumstances. Under the proposed system, if an immunity request was filed at an inauspicious time, the executive could simply defer ultimate resolution of the petition by granting temporary immunity. ${ }^{100}$

Additional advantages over the present system could be achieved by restricting the prospective and retroactive scope of the executive's exemption power. Confining prospective antitrust exemptions to a maximum time limit, say three years, would permit periodic reassessment without antagonizing the foreign governments involved, and it would also enhance the executive's accountability to Congress. ${ }^{101}$ In addition, the executive (as well as the judiciary) could be barred from immunizing private cartelists ${ }^{102}$ from antitrust liability incurred before the executive discovered the existence of the cartel. This restriction would prompt private cartel members to apprise the executive of their price-fixing activities during the formative stages of the cartel, thereby increasing the executive's bargaining leverage. ${ }^{103}$ Under the present system, even those cartels receptive to a negotiated settlement might opt for secrecy, reasoning that full retroactive immunity could be obtained through negotiations initiated once an antitrust suit is brought. ${ }^{104}$

99. Presumably, the court would stay the antitrust action pending the outcome of the negotiations. See supra note 92 .

100. In theory, the same result could be accomplished under the present system. $A$ court could invoke the judicial abstention doctrine and dismiss the case without prejudice to its resubmission if circumstances subsequently change. Such use of the judicial process, however, is too cumbersome and inefficient to merit serious attention.

101. Requiring the executive to inform the appropriate congressional committee of the reasons for its exemption determination as well as any subsequent developments would also facilitate congressional monitoring of the executive's use of its immunity authority.

102. The executive's authority to grant foreign government cartelists retroactive immunity should not be circumscribed in view of the potentially more severe foreign relations consequences of imposing antitrust liability on government entities. Affording the executive this added flexibility would not measurably reduce its ability to detect cartels. While the availability of complete retroactive immunity might induce foreign government cartelists to maintain secrecy, the private cartelists involved would have a compelling economic incentive to report to the executive.

103. To give present cartel members an incentive to disclose their involvement, the executive should be authorized to grant full or partial retroactive exemptions to any such private cartelist who reports to the executive in the year following enactment of this legislative proposal.

104. The antitrust exemption scheme urged here is superior in certain respects to the recent proposal by Rosenthal and Flowe described in their article, $A$ New Approach to U.S. Enforcement of Antitrust Laws Against Foreign Cartels, 6 N.C.J. INT'L L. \& COMM. REG. 81 (1980). These commentators have suggested several ways to improve the proposed Cartel Restriction Act of 1979, H.R. 4661, 96th Cong., 1st Sess. (1979) (requiring United States entities to report any efforts to solicit their 


\section{Conclusion}

The recent emergence of international cartels conducted or sponsored by foreign governments and their instrumentalities threatens significant interests of all consumer nations, including the United States. The availability of antitrust sanctions would greatly strengthen the ability of the executive to deter the formation or continuation of these multiple-nation cartels or at least to persuade these cartels to enter into diplomatic agreements requiring output expansion. Given the appreciable costs and risks incurred by a cartelist in removing its assets from the United States, monetary antitrust sanctions would frequently prove effective. In those occasional situations where the treble damage remedy could be evaded, an injunction barring the importation of the cartelized goods might prove effective.

To enhance the efficacy of antitrust sanctions, Congress should delegate to the executive the authority to grant antitrust exemptions to multiplenation cartels on grounds of comity or foreign relations. This proposal would not only enable the executive and judiciary to fulfill their proper institutional roles; it would also increase the executive's control over the timing of negotiations, thereby augmenting the value of the antitrust exemption as a bargaining item.

participation in an international cartel). Rosenthal and Flowe recommend that American cartel participants who disclose their involvement receive retroactive antitrust immunity if they agree to withdraw from the cartel and make restitution for the actual United States damages resulting from cartel price fixing. They also advocate that the Justice Department be empowered to grant petitions by foreign private and government prospective cartelists for immunity from future antitrust prosecution upon a finding that their proposed conduct would not violate the United States antitrust laws or would not be subject to the jurisdiction of United States courts.

While clearly preferable to the present system, the Rosenthal-Flowe legislative recommendation nevertheless is inadequate because it denies the executive the flexibility necessary to wrest valuable concessions from the cartels without unduly aggravating United States foreign relations. This inflexibility results from the failure to equip the executive with full exemption powers and from the narrowness of the standard that would govern the exercise of the executive's prospective immunity authority. Under this Note's proposal, the executive's exemption powers would not be so constrained.

The Rosenthal-Flowe plan would also fail to spur American and foreign cartelists into reporting their activities to the United States antitrust authorities. Under their scheme, current American cartelists would have an incentive to report only in the unlikely situation in which the expected value of continued cartel membership is a negative amount that (in absolute terms) exceeds the level of monopoly profits it reaped from the United States market. Moreover, prospective American and foreign participants in cartels that would affect significant United States markets would have no incentive to report since antitrust immunity would be unavailable in those circumstances. In contrast, the immunity scheme advanced here would encourage many such cartelists to report. By preventing the courts (via the judicial abstention doctrine) and the executive (via negotiations) from immunizing any private cartelist from treble damage judgments based on past monopoly profits, this proposal would not only eliminate the major benefit of cartel secrecy-the retention of past supra-competitive profits-but would also impose severe monetary penalties on non-reporting private cartelists. 